\title{
PELATIHAN MENULIS PUISI SISWA KELAS VI SDN 1 BAUBAU
}

\author{
Ruslan $^{1)}$ \& Nazriani ${ }^{2}$ \\ SDN Negeri 1 Kota Baubau ${ }^{1)}$ \\ Universitas Muhammadiyah Buton ${ }^{2)}$
}

\begin{abstract}
Abstrak
Kegiatan ini bertujuan untuk melatih siswa kelas VI SDN 1 Bauubau agar mampu menuangkan ide/gagasan, pikiran dan perasaannya melalui kegiatan menulis puisi, karena dengan melatih siswa menulis puisi diharapkan dapat meningkatkan daya pikir, daya imajinasi, daya kreatifitas siswa melalui pemilihan dan penyusunan kata lewat susunan bait dan baris serta dalam permainan bunyi. Metode yang digunakan adalah metode terbimbing dengan pendekatan proses yang dilakukan selama sehari dengan menghasilkan beberapa puisi karya siswa sesuai jumlah mereka di kelas. Berdasarkan hasil pelatihan tersebut dapat diketahui tema yang dipilih siswa merupakan tema yang dekat dengan dengan diri dan lingkungan mereka seperti ibu, ayah, guru, pahlawan, sahabat dan lain sebagainya. Bentuk tipografi yang digunakan masih menggunakan bentuk konvensional serta diksi yang digunakan masih bersifat denonatif.
\end{abstract}

Kata Kunci; Menulis, Puisi

\section{A. Pendahuluan}

Salah satu aspek keterampilan berbahasa yang perlu dimiliki oleh seseorang adalah keterampilan menulis. Menulis merupakan suatu upaya menyampaikan ide atau gagasan, perasaan, dan pengalaman seseorang melalui media tulisan. Pada dasarnya menulis merupakan upaya kreatif seseorang dalam mengekspresikan diri dan perasaannya serta mengolah kata ke dalam bentuk tulisan.

Dalam mata pelajaran bahasa Indonesia di sekolah khususnya di sekolah dasar tercantum standar kompetensi yang memuat keempat aspek keterampilan berbahasa (menyimak, berbicara, membaca, dan menulis). Keterampilan menulis merupakan salah satu aspek yang harus diajarkan kepada siswa sebab melalui keterampilan menulis siswa dapat menuangkan ide/gagan atau pengalamannya untuk dimanfaatkan baik untuk dirinya maupun untuk orang lain. 
Pelatihan ini khusus mengarah pada keterampilan menulis sastra yakni puisi. Sebab dengan melatih siswa menulis puisi diharapkan dapat meningkatkan daya pikir, daya imajinasi, daya kreatifitas siswa melalui pemilihan dan penyusunan kata lewat susunan bait dan baris serta dalam permainan bunyi.

\section{B. Landasan Teori}

\section{Pengertian Puisi}

Hudson yang mengutip pendapat Mc Caulay (Aminuddin, 2011: 134) mengungkapkan bahwa puisi adalah salah satu cabang sastra yang menggunakan kata-kata sebagai media penyampaian untuk membuahkan ilusi dan imajinasi, seperti halnya lukisan yang menggunakan garis dan warna dalam menggambarkan gagasan pelukisnya. Rumusan pengertian puisi di atas masih bisa diterima karena kita sering kali diajuk oleh suatu ilusi tentang keindahan penataan unsur bunyi, penciptaan gagasan, maupun suasana tertentu sewaktu membaca sebuah puisi.

Puisi merupakan salah satu jenis karya sastra selain prosa dan drama. Perbedaan di antara ketiga karya sastra ini terlihat pada tipografinya, kata-katanya yang padat serta menggunakan rima yang unik dan menarik. Luxemburg dkk (1992: 177) mengungkapkan beberapa ciri khusus puisi yang sering muncul yaitu tematik. Tematik sering dikenal dengan istilah lirik. Situasi bahasa yang bersifat monolog dikembangkan menjadi ungkapan si Aku lirik yang ditujukan kepada pendengar, seorang kekasih, gejala alam yang dipersonifikasikan, penyair sendiri atau pembaca. Tema dalam puisi dibangun dengan cara yang berbeda dengan yang ada dalam teks naratif atau drama. Banyak yang tidak diungkapkan secara eksplisit. Kaidah-kaidah logika dalam bahasa tidak berlaku. Dalam puisi pola-pola semantik sangat diperlukan. Variasi dalam hal sintaksis, bunyi, dan bentuk sajak merupakan gejala-gejala formal yang juga mempunyai makna

Puisi pada dasarnya mempunyai dua unsur yaitu surface stucture (struktur luar) dan deep structure (struktur dalam) (fananie, 2000: 99). Struktur luar puisi berkaitan dengan bentuk, sedangkan unsur dalam berkaitan dengan isi atau makna. Struktur luar terdiri atas pilihan kata (diksi), struktur bunyi, penempatan kata dalam kalimat, penyususnan kalimat, penyususnan bait dan 
tipografi. Adapun struktur dalam adalah struktur yang berhubungan dengan tema, pesan, atau makna yang tersirat di balik struktur luar.

a. Struktur luar (surface structure)

1. Pilihan kata (diksi)

Pilihan kata merupakan hal yang esensial dalam struktur puisi karena kata merupakan wahana ekspresi utama. Setiap kata akan mempunyai beberapa fungsi, baik fungsi makna, fungsi bunyi, maupun fungsi pengungkapan nilai estetika bentuk lainnya. Kata yang dipilih harus mampu mengungkapkan satu ekspresi yang dapat melahirkan pesan-pesan tertentu tanpa meninggalkan aspek estetisnya. Untuk menghadirkan efek-efek tersebut maka pilihan kata bisa saja diambil dari kata-kata yang mengandung makna leksikal atau makna denotatif atau juga katakata yang mengandung makna konotatif dan simbolis. Karena sifat puisi adalah multiintrepertabel, kata-kata yang bermakna simbolis umumnya menjadi pilihan dari para pengarang puisi.

\section{Unsur Bunyi}

Unsur bunyi merupakan penataan kata dalam struktur kalimat (Fananie, 2000:103). Pada puisi lama seperti pantun dan syair, penyusunan bunyi merupakan bagian yang mutlak karena struktur tersebut merupakan bagian penanda bentuk. Pada pantun, misalnya, struktur bunyi selalu bersajak ab-ab, sedangkan pada syair struktur bunyi selalu bersajak aa-aa. Namun, pada puisi baru atau puisi kontemporer struktur penyusunan bunyi tidak lagi melalui satu patokan khusus. Meskipun demikian, persoalan bunyi pada puisi baru masih tetap merupakan bagian yang tidak terpisahkan dalam kaitan memunculkan ekspresi estetik. Adanya ketidakbakuan struktur bunyi pada puisi baru atau kontemporer menyebabkan variasi bunyi yang dimunculkan pengarang menjadi sangat beragam.

a. Rima

Rima yaitu bunyi-bunyi yang sama dan diulang baik dalam satuan kalimat maupun pada kalimat-kalimat berikutnya. Pengulangan bukanlah pengulangan dalam arti model sampiran seperti halnya yang terdapat dalam pantun, melainkan 
pengulangan yang dimaksud untuk memberikan efek tertentu. Rima tersebut dapat berupa:

- Asonansi atau keruntutan vokal yang ditandai oleh persamaan bunyi vokal pada satu kalimat

- Aliterasi atau purwakanthi, yaitu persamaan bunyi konsonan pada kalimat atau antarkalimat dalam puisi.

- Rima dalam, yaitu persamaan bunyi (baik vokal maupun konsonan) yang berlaku antara kata dalam satu baris.

- Rima akhir, yaitu persamaan bunyi pada akhir baris.

b. Irama

Irama yaitu paduan bunyi yang menimbulkan aspek musikalitas atau ritme tertentu. Ritme tersebut bisa muncul karena adanya penataan rima, pemberian eksentuasi, intonasi dan tempo ketika puisi itu dibaca

b.Struktur dalam (Deep Structure)

Deep structure atau struktur dalam pada dasarnya adalah makna yang terkandung di balik kata-kata yang disusun sebagai struktur luarnya. Pengertian struktur dalam diberikan karena makna dalam puisi sseringkali merupakan makna yang tidak langsung atau makna simbolis, makna yang kemunculannya perlu diintrepretasikan, direnungkan, dikaitkan antara keberadaan kata yang satu dengan kata yang lain, antara keberadaan fenomena yang satu dengan fenomena yang lain. Oleh karena itu, makna yang berhubungan dengan deep structure bergantung pula pada kepekaan, pengalaman, pengetahuan, dan ketajaman intiusi pembaca. Dengan demikian, makna-makna yang tersirat umumnya bersifat subjektif dan relatif. (Fananie, 2000:104).

Berdasarkan uraian teori di atas dapatlah dikatakan bahwa puisi yang bai adalah puisi yang memenuhi unsur-unsur tersebut. Unsur tersebut merupakan totalitas dalam mencipta suau karya sastra (puisi).

2. Pengertian Menulis Puisi

Jabrohim (2003:68) menyatakan bahwa menulis puisi merupakan suatu kegiatan seseorang 'inteletual', yaitu kegiatan yang mengharuskan seseorang harus cerdas, dapat menguasai bahasa, memeliki wawasan yang luas, serta peka 
perasaannya. Syarat tersebut harus benar-benar ada agar puisi yang dihasilan bukan puisi sentimental. Sementara itu Wijayanto (2005: 57) menyatakan bahwa menulis puisi itu sebenarnya mengungkapkan gagasan dalam bentuk puisi.

Berdasarkan uraian pengertian di atas maka dapatlah dikatakan bahwa keterampilan menulis puisi merupakan keterampilan kreativitas yang imajinatif untuk mengkspresikan diri yang berisi luapan perasaan, emosi, serta gagasan seseorang.

\section{Langkah-langkah Menulis Puisi}

Sesorang yang akan memulai menulis khususnya menulis puisi perlu kiranya memperhatikan langkah-langkah menulis puisi, agar puisi yang dihasilan dapat memenuhi kriteria puisi yang baik. adapaun langkah-langkah tersebut adalah:

a. menentukan tema.

b. menentukan pilihan kata / diksi.

c. memperhatikan gaya bahasa atau majas yang digunakan.

d. memperhatikan enjabemen.

e. memperhatikan estetika.

f. menentukan makna yang terkandung dalam puisi tersebut.

\section{Metode Pengambilan Data}

Metode yang digunakan dalam pelatihan ini adalah metode deskriptif kualitatif. Metode pengambilan data menggunakan latihan terbimbing dan penugasan. Adapun pendekatan yang digunakan adalah pendekatan keterampilan proses.

1. Lokasi Pengabdian

Lokasi pengabdian yaitu di SDN 1 Baubau jalan R.A Kartini No.19 Kota Baubau

2. Waktu Pelaksanaan

Kegiatan berlangsung selama sehari yaitu tanggal 15 Januari 2019 bertepatan dengan jam mata pelajaran bahasa dan Sastra Indonesia.

3. Tahap-tahap Kegiatan

\begin{tabular}{|l|l|l|}
\hline Hari,Tanggal & Kegiatan & Hasil \\
\hline Selasa, 15 & Menjelaskan puisi & Siswa antusias \\
\hline
\end{tabular}




\begin{tabular}{|c|c|c|}
\hline \multirow[t]{8}{*}{ Januari 2019} & $\begin{array}{l}\text { Menampilkan contoh-contoh puisi } \\
\text { Membaca puisi yang ditampilkan }\end{array}$ & $\begin{array}{l}\text { dalam membaca } \\
\text { puisi-puisi yang } \\
\text { ditampilkan }\end{array}$ \\
\hline & $\begin{array}{l}\text { Menyiapkan siswa untuk mulai } \\
\text { menulis }\end{array}$ & \\
\hline & $\begin{array}{l}\text { Memunculkan ide-ide yang ingin } \\
\text { ditulis siswa }\end{array}$ & $\begin{array}{l}\text { Siswa banyak } \\
\text { mengambil tema } \\
\text { yang terdekat } \\
\text { dengan dirinya. }\end{array}$ \\
\hline & Mematangkan dan mengolah ide & $\begin{array}{l}\text { Siswa membuat } \\
\text { puisi dengan } \\
\text { mengumpulkan } \\
\text { kata-kata yang } \\
\text { mendukung }\end{array}$ \\
\hline & $\begin{array}{ll}\text { - } & \text { Mengungkapkan ide } \\
\text { atau pengekspresian } \\
\text { - Melatih siswa untuk } \\
\text { memperkaya kosa } \\
\text { kata } \\
\text { - Menyusun rima }\end{array}$ & $\begin{array}{l}\text { Siswa mencari } \\
\text { kata berupa kata } \\
\text { sinonim dan kata } \\
\text { konotasi. } \\
\text { Memilih rima } \\
\text { yang pas }\end{array}$ \\
\hline & & $\begin{array}{l}\text { Kata yang } \\
\text { terkumpul } \\
\text { dimasukan dan } \\
\text { diatur bentuknya }\end{array}$ \\
\hline & & $\begin{array}{l}\text { Kata yang tidak } \\
\text { dipakai dibuang }\end{array}$ \\
\hline & $\begin{array}{l}\text { Memberikan motivasi kepada siswa } \\
\text { agar tetap menulis puisi }\end{array}$ & $\begin{array}{l}\text { Siswa } \\
\text { mengumpulkan } \\
\text { puisinya }\end{array}$ \\
\hline
\end{tabular}




\section{Pembahasan}

Berdasarkan hasil pengamatan serta pelatihan selama kegiatan berlangsung terlihat antusiasme siswa dalam menulis puisi. Hal ini terlihat dalam setiap tahap kegiatan para siswa rajin bertanya dan meminta untuk dilihat oleh tim hasil tulisannya. Pelatihan ini menghasilkan 26 buah puisi. Tema yang dipilih adalah ibu (15 puisi), ayah (1 puisi), guruku (5 puisi), sahabatku (3 puisi), pahlawanku (2 puisi). Tema ini dijadikan judul puisi.

Jika dicermati isi puisi yang ditulis oleh siswa kelas VI SDN 1 Baubau secara umum menggambarkan tentang rasa cinta terhadap ibu dan ayah, rasa bangga dan hormat terhadap jasa para pahlawan, ucapan terima kasih kepada guru serta ungkapan sayang terhadap sahabat. Diksi yang digunakan pun masih bersifat denotasi namun tidak mengurangi makna dan tujuan puisi.

Puisi yang dibuat oleh siswa belum sepenuhnya menggunakan permainan bunyi atau rima, sekalipun dalam pelatihan diajarkan tentang rima dan irama dalam puisi. Selain itu bentuk tipografi yang dibuat siswa masih konfensional.

\section{E. Kesimpulan}

Melalui pelatihan ini siswa sangat termotifasi dalam menulis puisi. Menulis puisi sangat dianjurkan bagi siswa sebab dengan menulis puisi siswa dapat mengungkapkan perasaannya serta dapat menunjang ketrampilan berbahasanya dan dapat meningkatkan rasa kepercayaan diri mereka. Pendekatan proses yang dilakukan dalam pelatihan ini cukup efektif dan mampu meningkatkan semangat belajar khususnya menulis puisi. Walaupun dilakukan selama sehari namun penulis menyadari masih banyak kekurangannya, untuk itu agar dapat menghasilkan puisi yang lebih baik lagi diharapkan agar dapat menggunakan pendekatan yang lebih baik lagi

\section{Daftar Pustaka}

Endswara, Suwardi.2003. Membaca, Menulis, Mengajarkan sastra. Yogyakarta: FBS UNY. 
Fananie, Zainuddin. 2000. Telaah Sastra. Surakarta: Muhammadiyah University Press.

Jabrohim, dkk.2003. Cara Menulis Kreatif. Yogyakarta: Pustaka Pelajar.

Wijayanto, Asul. 2005. Kesusastraan Sekolah.Jakarta: Grasindo. 